\title{
Sandeel recruitment in the North Sea: demographic, climatic and trophic effects
}

\author{
Stephen A. Arnott*, Graeme D. Ruxton \\ Division of Environmental \& Evolutionary Ecology, Faculty of Biomedical and Life Sciences, University of Glasgow, \\ Glasgow G12 8QQ, United Kingdom
}

\begin{abstract}
The lesser sandeel Ammodytes marinus, which is one of the most abundant fish in the North Sea, has highly variable recruitment dynamics. We evaluate potential associations between their recruitment and some key biological and physical factors. Population data were analysed at the North Sea scale (years 1983 to 1999) and at the regional scale (southwestern section and northeastern section; years 1984 to 1996/7). Relationships between recruitment and spawning stock biomass were weak, but Age-1 sandeels (non-spawners) were related negatively with recruitment, implying that demographic effects are important. A negative relationship was detected between recruitment and the winter index of the North Atlantic Oscillation, which affects sea temperatures during the egg and larval period. Warmer sea temperatures correlated with poorer than average recruitment. This effect was most pronounced in the southwestern part of the North Sea, which is near the southern limit of the species' distribution. There was a positive association between recruitment and Calanus copepod (Stages V and VI) abundance around the time of larval hatching, suggesting that the availability of this prey species is important for young sandeel survival. Our findings suggest that climate change may impact upon sandeel populations in the North Sea.
\end{abstract}

KEY WORDS: Ammodytes · Calanus - Climate - Larvae - North Atlantic Oscillation · Recruitment · Sandeel · Temperature

\section{INTRODUCTION}

Recruitment can be defined as the number of individuals in a population that reach a specified stage of an organism's life cycle (Jennings et al. 2001), and understanding the processes that control it is of fundamental importance to population biologists. In the context of commercial fisheries, a target species' recruitment is usually assessed as the number of individuals alive at the age when they first appear within the catches. Therefore, recruitment (to a closed population) depends upon the number of eggs that are produced by spawning adults, and the mortality rate of the

\footnotetext{
*Present address: Marine Sciences Research Center, Stony Brook University, Stony Brook, New York 11794-5000, USA. E-mail: sarnott@ms.cc.sunysb.edu
}

eggs, larvae and juveniles between the time when they are laid and the age when they are first caught.

A common means of analysing the population dynamics of a fished species is to use population assessment records to generate predictions of recruitment, which are based upon the number of eggs thought to be produced in the population. Egg production can be calculated from estimates of spawner abundance, size, fecundity and number of spawning events, but often simply the spawning stock biomass (SSB) is instead used as a proxy for egg production. The relationship between recruitment and SSB can be described by various theoretical curves, which have inherent density-dependent assumptions controlling the non-linear association between recruitment and SSB. Well-known examples include the Beverton-Holt relationship (Beverton \& Holt 1957), the Ricker relationship (Ricker 1954) and the Shepherd relationship 
(Shepherd 1982). Although these curves are extensively used for making recruitment predictions and setting landing limits, data are often scattered widely about these fitted curves.

In many marine fishes, egg production can be several orders of magnitude greater than recruitment due to the huge fecundity of spawners and the massive mortality suffered by early life stages. Thus, any factor that influences early life stage mortality can have profound effects upon recruitment, and can cause deviation about the SSB-recruitment curve. This realisation (Hjort 1914) has led to extensive fields of research into the biological and physical factors controlling mortality during early life stages in fishes.

Of the biological factors, predation threat and food availability are 2 of the principle processes that have received attention. Newly hatched larvae are especially vulnerable to predation due to their small size and poorly developed sensory and escape capabilities (Blaxter \& Batty 1985, Blaxter \& Fuiman 1990). In some species, cannibalism by older age classes may present an added source of predation, and in such cases, the demographic structure of population can have important consequences for juvenile survival (Bailey \& Houde 1989). Food availability is also important because the juvenile stages have high development and per-unit-mass metabolic rates, which put them at risk of starvation unless sufficient prey is available soon after hatching (Cushing 1975, Pope et al. 1994). Physical factors (e.g. ocean currents, upwelling, turbulence and temperature) are important because they have direct effects upon larval growth, development and transport, and indirect effects via, for example, prey and/or predator abundance (e.g. Hayward 1997, Hofmann \& Powell 1998, Hollowed et al. 2001).

In this paper, we evaluate the recruitment dynamics of the lesser sandeels Ammodytes marinus in the North Sea with respect to SSB, demographic structure of the population, climatic processes and zooplankton (prey) abundance. Sandeels are a key component of the North Sea ecosystem, forming an important trophic link between zooplankton production and higher predator species (Greenstreet 1996). A commercial fishery for sandeels (predominantly A. marinus) began in the 1950s and remained comparatively small (landings $<200000 \mathrm{t} \mathrm{yr}^{-1}$ ) until the fishery started to expand rapidly in the early 1970s. Since the mid-1980s, annual landings have fluctuated about a mean of $820000 \mathrm{t}$, ranging between 580000 and $1100000 \mathrm{t}$ (Anonymous 2001). No catch forecasts are made for the fishery because the recruitment dynamics are highly erratic. One reason for this is that the species is fairly short lived. Most individuals are sexually mature at $2 \mathrm{yr}$ (Macer 1966, Gauld \& Hutcheon 1990), and few survive beyond 3 to 4 yr because of their high natural mor- tality rate (Anonymous 2001). Thus, SSB is highly dependent upon recruitment in recent years.

Ammodytes marinus lay demersal eggs between November and January, and their planktonic larvae are present in the water column between late January and May (Henderson 1953, Reay 1970, Hart 1974). Thereafter, the juveniles settle onto seabed areas with course, sandy substrata (Wright et al. 2000). In the summer months, they form large schools in the water column during the daytime, feed on zooplankton and bury themselves within the substratum at night. With the onset of winter, they cease feeding and mostly remain buried until the following spring (Winslade 1974a,b,c).

Since the relationship between SSB and recruitment is very scattered in North Sea sandeels (Anonymous 2001, Arnott et al. 2002), the aim of this study was to test whether recruitment is affected by additional factors that might influence survival between the time of hatching and the time when 0-group fish first appear in the commercial catches (soon after they settle onto the seabed; Anonymous 2001).

The demographic structure of the sandeel population was explored because it has been postulated that non-spawning (1-group) sandeels may have densitydependent effects that are unaccounted for within the SSB-recruitment relationships (Furness 1999, Arnott et al. 2002). This is because 1-group sandeels are usually more numerous than the Age-2+ spawning sandeels (Anonymous 2001).

The main physical parameter we evaluate is the North Atlantic Oscillation (NAO). The NAO is a largescale climatic phenomenon that influences wind, rainfall and temperature regimes throughout the North Atlantic and its surrounding land masses. Monthly indices of NAO are based upon the difference in normalised atmospheric pressures (at sea level) between Lisbon, Portugal and Stykkisholmur/Reykjavik, Iceland. Positive winter indices (averaged over December to March) are known to correlate with strong winter storms crossing the Atlantic Ocean along northerly tracks, resulting in warmer, windier and wetter than average winters in the vicinity of the northeast Atlantic. Negative indices are associated with colder and drier winters (Hurrell 1995). The NAO has profound and widespread effects upon terrestrial, freshwater and marine ecosystems (e.g. Ottersen et al. 2001), and has been shown to have an influence across a number of trophic levels in the North Sea (e.g. Heyen et al. 1998, Reid et al. 1998, O'Brien et al. 2000, Thompson \& Ollason 2001).

We have performed further analyses using sea temperature data, since the NAO winter index correlates positively with sea temperature during late winter and early spring in the North Sea (Becker \& Pauly 1996) (i.e. the months when sandeel larvae are developing). 
One expectation in this respect, might be that higher than average temperatures have a negative effect upon sandeel recruitment. This is because sandeels in the North Sea approach the southern limit of the species distribution (Reay 1970) and they are therefore near the warmer climatic extremes to which they are adapted. Under such circumstances, fish stocks are likely to have poorer than average recruitment in warm years (Myers 1998).

To test for potential relationships between food availability and recruitment, the effects of Calanus copepod abundance have been examined, since these are an important prey item for larval sandeels (Reay 1970). In particular, we hypothesise that, if feeding conditions are important, Calanus abundance during the larval stages should be positively associated with recruitment, since this would reduce the likelihood of starvation.

\section{MATERIALS AND METHODS}

Sandeel population data. Sandeel spawning stock biomass $(S)$ in January, the number of 1-group sandeels in January $\left(N_{1}\right)$ and the number of 0 -group recruits in July $\left(N_{0}\right)$ in the North Sea population as a whole were taken from the most recent single-species virtual population analyses (SSVPA) of sandeel fisheries data for the period 1983 to 1999 (Anonymous
2001). The data do not include Shetland sandeels (northwestern portion of North Sea), since this fishery is assessed separately. Recruitment of the 2000 year class was not included in the analyses because its calculation was based on limited landings and sampling (0-group fish only constitute a small proportion of the catch) and was very sensitive to model assumptions. As such, the 2000 datum was considered to be preliminary and an unreliable estimate of recruitment by the authors of the report (Anonymous 2001).

There is some evidence that North Sea sandeels comprise a number of sub-populations that have restricted mixing between them, rather than a single population (Procter et al. 1998). Although population assessments are usually reported at the whole North Sea level, SSVPA assessments for two of the main subpopulations identified by Procter et al. (1998) have been performed by Pedersen et al. (1999). Regional population data for Regions 1 and 2 were taken from these assessments covering the periods 1983 to 1996 and 1983 to 1997, respectively. Region 1 covers most of the North Sea area to the west of $4^{\circ} \mathrm{E}$ lying between 51 and $56^{\circ} \mathrm{N}$. Region 2 covers most of the area to the east of $1^{\circ} \mathrm{E}$ lying between $55^{\circ} 30^{\prime} \mathrm{N}$ and $59^{\circ} \mathrm{N}$ (Fig. 1). For Region $2, N_{0}$ in July was used as an estimate of recruitment (as above, with the whole North Sea data). For Region 1, no $N_{0}$ data were available, so instead $N_{1}$ in January the year after settlement was taken as a mea-
Fig. 1. Assessment areas. The whole North Sea sandeel assessment data cover Areas IVa, IVb and IVC, excluding the Shetland box. Temperature and zooplankton data are from Area IVb, where the majority of sandeels are caught. Regions 1 and 2 represent the areas considered in the population assessments of Pedersen et al. (1999). Numbers along axes indicate latitude and longitude

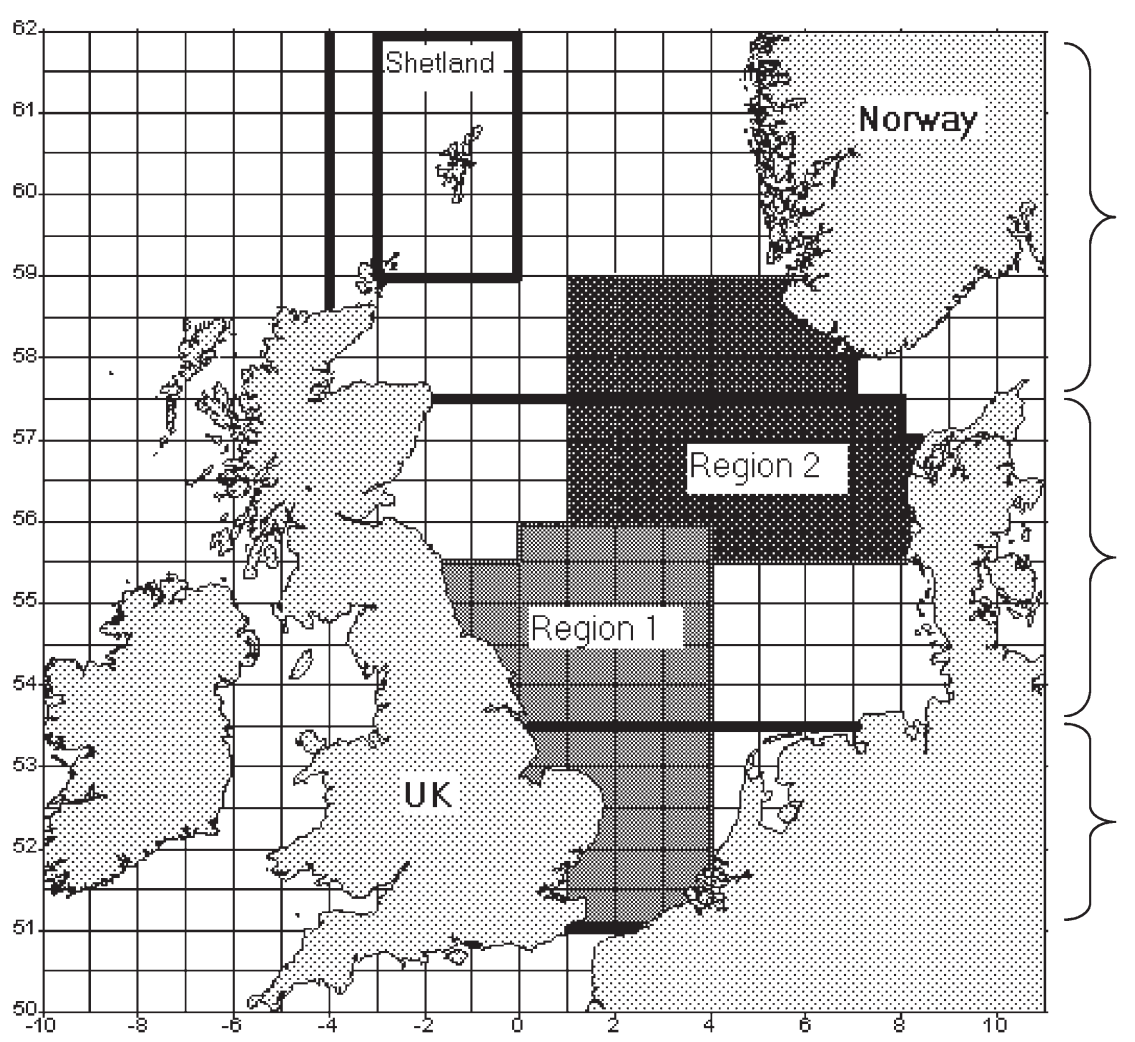

North Sea

Area IVa

North Sea Area IVb

North Sea Area IVc 
sure of recruitment (note that $N_{0}$ in July and $N_{1}$ the following January are highly correlated in the other assessments: for both the whole North Sea and Region 2, $\mathrm{r}>0.99, \mathrm{p}<0.0001)$.

Climatic data. NAO winter indices $\left(I_{\mathrm{NAO}}\right.$, the mean of the December to March monthly indices) were obtained from the internet site of J. W. Hurrell at (www.cgd.ucar.edu/ jhurrell/nao.html\#winter; also see Hurrell 1995). The values are based on the difference of normalised sea level pressure between Lisbon, Portugal and Stykkisholmur/Reykjavik, Iceland, since 1864. The sea level pressure anomalies at each station that were used for calculating the indices were normalised by division of each seasonal mean pressure by the long-term mean SD (1864 to 1983).

Monthly mean sea bottom $\left(T_{\mathrm{b}}\right)$ and sea surface $\left(T_{\mathrm{s}}\right)$ temperature data were provided by the International Council for the Exploration of the Sea (ICES; Copenhagen, Denmark). Temperature data are averaged across ICES area IVb (spanning the central North Sea from $53^{\circ} 30^{\prime} \mathrm{N}$ to $57^{\circ} 30^{\prime} \mathrm{N}$; see Fig. 1), which intersects Regions 1 and 2 and covers most of the intensely fished sandeel grounds in the North Sea (Anonymous 1999, Pedersen et al. 1999). Sea bottom and surface temperatures were investigated because the early life stages experience both water bodies (the eggs are demersal; the larvae are planktonic and undergo vertical migrations; the metamorphosed juveniles settle onto the seabed but feed in the water column).

Zooplankton data. Zooplankton data were provided by the Sir Alister Hardy Foundation for Ocean Science (Plymouth, UK), and covered 1983 to 1997 (data for 1998 and 1999 were not available). Monthly counts of Calanus Stage V and VI copepods $\left(C_{\mathrm{v}-\mathrm{vi}}\right)$ were obtained from continuous plankton recorder surveys. The values used in the analyses are for ICES area IVb (as described above) and were $\log _{10}$ transformed.

Recruitment functions. Relationships between recruitment and spawning stock biomass were investigated using a Ricker function (Hilborn \& Walters 1992). Coefficients were fitted by least-squared linear regression to the linearised version of the model:

$$
\ln \left(\frac{N_{0}}{S}\right)=a S+k
$$

where $N_{0}$ is the number of recruits (billions), $S$ is the spawning stock biomass (1000s of tonnes), and $a$ and $k$ represent fitted coefficients. The significance of each coefficient within the model was tested by $t$-test (Minitab v.13.31 software, Minitab).

Additional independent variables were added to the model by extending the Ricker function into a multiple regression (Hilborn \& Walters 1992). The function used for modelling the effects of both $S$ and $N_{1}$ abundance took the form:

$$
\ln \left(\frac{N_{0}}{S}\right)=a S+b \ln \left(N_{1}+1\right)+k
$$

where $N_{1}$ represents 1-group abundance in billions (ln transformed to meet normality criteria). Further extension of the model to include an environmental variable took the form:

$$
\ln \left(\frac{N_{0}}{S}\right)=a S+b \ln \left(N_{1}+1\right)+c E+k
$$

where $E$ represents the environmental variable (e.g. $I_{\text {NAO }}$ or temperature).

Correlation analyses. Autocorrelation coefficients of recruitment data and regression residuals were calculated according to Chatfield (1996). $N_{0}$ data were ln transformed in order to meet normality criteria.

Pearson product moment correlation coefficients were calculated from comparisons between recruitment data and 1-group abundance, and between recruitment data and environmental data $\left(N_{0}\right.$ and $N_{1}$ data were $\ln$ transformed). Several series of correlations were generated between recruitment and monthly $T_{\mathrm{b}}$, $T_{\mathrm{s}}$ and $C_{\mathrm{v} \text {-vi }}$ data, whereby recruitment was compared with the environmental measure of interest for each of the 12 mo prior to the year of recruitment, as well as the 12 mo covering the actual recruitment year (total of 24 mo, i.e. $R_{y}$ vs $E_{1, y-1}, R_{y}$ vs $E_{2, y-1} \ldots . R_{y}$ vs $E_{12, y}$ etc., where $R_{Y}$ represents a recruitment value for Year $y$ and $E_{X, Y}$ represents an environmental parameter during Month $x$ of Year $y$ ). Values of $R_{y}$ comprised either $N_{0}$ (ln transformed), or recruitment residuals from Eq. (2). We hypothesised that any correlations with environmental data from the months prior to egg laying (approximately January) might suggest indirect effects upon recruitment (e.g. by affecting parental gamete production and viability), whereas correlations during the egg/larval stage months would suggest more direct effects acting upon the young developmental stages. We did not expect to find any significant correlations after June of the actual recruitment year, since $N_{0}$ values in the population assessments are estimates of recruitment numbers in July. As recruitment data were correlated across 24 different months of environmental data within each correlation series, Type I errors were accounted for by applying a Bonferroni correction factor. Hence, the level of significance was adjusted to 0.002 (i.e. 0.05/24).

\section{RESULTS}

\section{Relationship between recruitment and $N_{1}$}

In all 3 of the population data sets, a significant negative correlation was found between $N_{0}$ and $N_{1}$ (both ln transformed). Correlation coefficients for the whole North Sea, Region 1 and Region 2 were -0.563 ( $p=$ 
Table 1. Fitting of recruitment models for sandeels in the whole North Sea (1983 to 1999), Region 1 (1983 to 1996) and Region 2 (1983 to 1997). $N_{0}$ represents the number of recruits (billions), $S$ is spawning stock biomass (1000s of tonnes), $N_{1}$ is the number of Age- 1 sandeels $\left(\times 10^{8}\right)$ in January and $I_{\text {NAO }}$ is the North Atlantic Oscillation winter index. The values $a, b, c$ and $k$ are coefficients fitted to the model by least-squares linear regression. The significance of each coefficient was tested by $t$-test. In Region 1 ,

$N_{1}$ was used as estimate of recruitment the year before - see 'Materials and methods'. ${ }^{*} \mathrm{p}<0.05{ }_{i}{ }^{* *} \mathrm{p}<0.01{ }_{i}{ }^{* * *} \mathrm{p}<0.001$

\begin{tabular}{|lccccc|}
\hline Model & Coefficient & & \multicolumn{2}{c|}{$\begin{array}{c}\text { Fitted coefficients } \\
\text { Region } 1\end{array}$} \\
\hline Eq. (1) & & North Sea & -0.0018 & $-0.0038^{* *}$ \\
$\ln \left(N_{0} / S\right)=a S+k$ & $a$ & $-0.0010^{*}$ & -0.8921 & $+0.7297^{*}$ \\
Eq. (2) & & $k$ & +0.5013 & $-0.0031^{*}$ & $-0.0040^{* *}$ \\
$\ln \left(N_{0} / S\right)=a S+b \ln \left(N_{1}+1\right)+k$ & $a$ & $-0.0016^{* * *}$ & $-0.6953^{*}$ & $-0.6478^{*}$ \\
& & $b$ & $-0.7175^{* *}$ & +2.396 & $+3.5420^{* *}$ \\
Eq. (3) & & $k$ & $+5.008^{* *}$ & $-0.0042^{* * *}$ & $-0.0037^{* *}$ \\
$\ln \left(N_{0} / S\right)=a S+b \ln \left(N_{1}+1\right)+I_{\text {NAO }}+k$ & $a$ & $-0.0019^{* * *}$ & $-0.6277^{*}$ & $-0.5640^{*}$ \\
& & $b$ & $-0.8002^{* * *}$ & $-0.1963^{*}$ & -0.1122 \\
& & $k$ & $-0.1405^{* *}$ & $+2.739^{*}$ & $+3.277^{* *}$ \\
\hline
\end{tabular}

$0.019, \mathrm{n}=17),-0.648(\mathrm{p}=0.017, \mathrm{n}=13)$ and -0.568 $(\mathrm{p}=0.034, \mathrm{n}=14)$, respectively.

Fitting the recruitment data according to Eq. (1) ( $S$ as the only independent variable) produced less satisfactory results than Eq. (2) ( $S$ and $N_{1}$ as independent variables) and revealed that the coefficient for $\ln \left(N_{1}+1\right)$ in Eq. (2) was significantly negative in all cases (North Sea: $\mathrm{p}=0.007$; Region 1: $\mathrm{p}=0.026$; Region 2: $\mathrm{p}=0.025$; see Table 1).

\section{North Atlantic Oscillation}

Direct correlations between $N_{0}$ (ln transformed) and $I_{\text {NAO }}$ produced negative coefficients, but none differed significantly from 0 (North Sea: $r=-0.355, \mathrm{p}=0.162$; Region 1: $\mathrm{r}=-0.536, \mathrm{p}=0.059$; Region 2: $\mathrm{r}=-0.317$, $\mathrm{p}=0.269$ ).

Controlling for the effects of $S$ and $N_{1}$ strengthened these negative relationships ( $I_{\mathrm{NAO}}$ vs residuals from Eq. 2; North Sea: $\mathrm{r}=-0.601, \mathrm{p}=0.011$; Region 1: $\mathrm{r}=$ $-0.552, \mathrm{p}=0.050$; Region 2: $-0.492, \mathrm{p}=0.074)$. Thus, years with a strong positive $I_{\mathrm{NAO}}$ correspond with years in which recruitment is lower than expected.

The results from fitting the recruitment data according to Eq. (3) ( $S, N_{1}$ and $I_{\mathrm{NAO}}$ as independent variables) reveal that the coefficient for $I_{\mathrm{NAO}}$ was negative in all instances, and was significant at the whole North Sea level ( $p<0.01)$ and in Region 1 ( $p=0.028)$, but not in Region 2 ( $p=0.091$; see Table 1$)$.

\section{Temporal periodicity of recruitment}

The autocorrelation coefficients (Table 2) of the $N_{0}$ time series data (ln transformed), at a lag of $1 \mathrm{yr}$, were significantly negative for all 3 population data sets, indicating that a strong recruitment year is generally followed by a weaker recruitment year, and vice versa. The residuals derived from the $S$ model (Eq. 1) produced very similar results, but the lag-1 autocorrelations were no longer significant after the effects of $N_{1}$ were accounted for (residuals from Eq. 2). Residuals from the $S+\ln \left(N_{1}+1\right)+I_{\text {NAO }}$ model (Eq. 3) produced similar results to those from Eq. (2).

\section{Sea temperature}

For the period covered by our data (North Sea recruitment time series: 1983 to 1999), I $I_{\mathrm{NAO}}$ was positively correlated with mean monthly sea bottom $\left(T_{\mathrm{b}}\right)$ and sea surface $\left(T_{\mathrm{S}}\right)$ temperatures during the first half of the year (Fig. 2A,E).

Comparisons betweexn sea temperature data and $N_{0}$ (ln transformed) produced 1 correlation that was significant at the Bonferroni corrected level ( $p=0.002)$; in Region $1, T_{\mathrm{s}}$ in April was negatively related to $N_{0}$ in the

Table 2. Autocorrelation coefficients, at a lag of $1 \mathrm{yr}$, for recruitment data from the whole North Sea, and from Regions 1 and 2 . Values have been calculated using the normalised recruitment data $\left(\ln \left[N_{0}+1\right]\right)$, and using residuals from recruitment Eq. (1) ( $S$ as independent variable), Eq. (2) ( $S$ and $N_{1}$ as independent variables) and Eq. (3) $\left(S, N_{1}\right.$ and $I_{\text {NAO }}$ as independent variables). ${ }^{*}$ Autocorrelation coefficients significant at the $5 \%$ level or less

\begin{tabular}{|llccc|}
\hline & $\ln \left(N_{0}+1\right)$ & $\begin{array}{c}\text { Eq. (1) } \\
\text { residuals }\end{array}$ & $\begin{array}{c}\text { Eq. (2) } \\
\text { residuals }\end{array}$ & $\begin{array}{c}\text { Eq. (3) } \\
\text { residuals }\end{array}$ \\
\hline North Sea & $-0.52^{*}$ & $-0.55^{*}$ & -0.04 & -0.14 \\
Region 1 & $-0.51^{*}$ & $-0.51^{*}$ & -0.22 & -0.31 \\
Region 2 & $-0.48^{*}$ & $-0.44^{*}$ & -0.14 & -0.17 \\
\hline
\end{tabular}


Sea bottom temperature
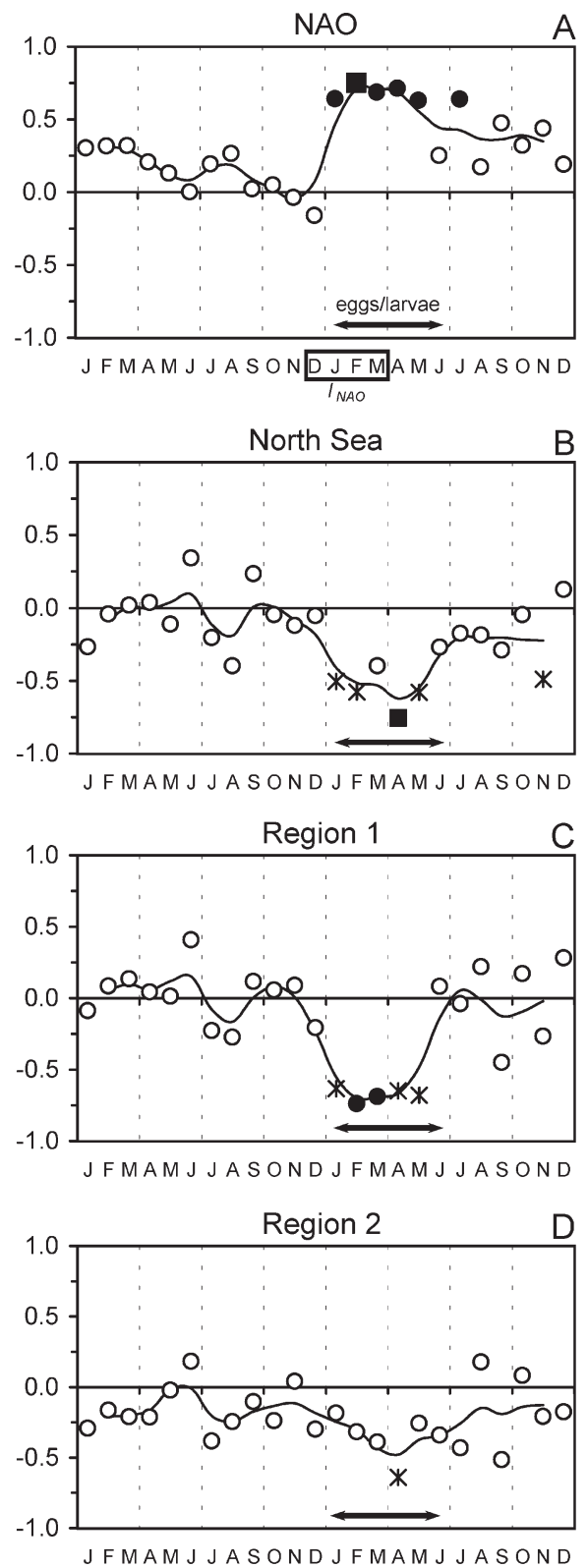

Sea surface temperature
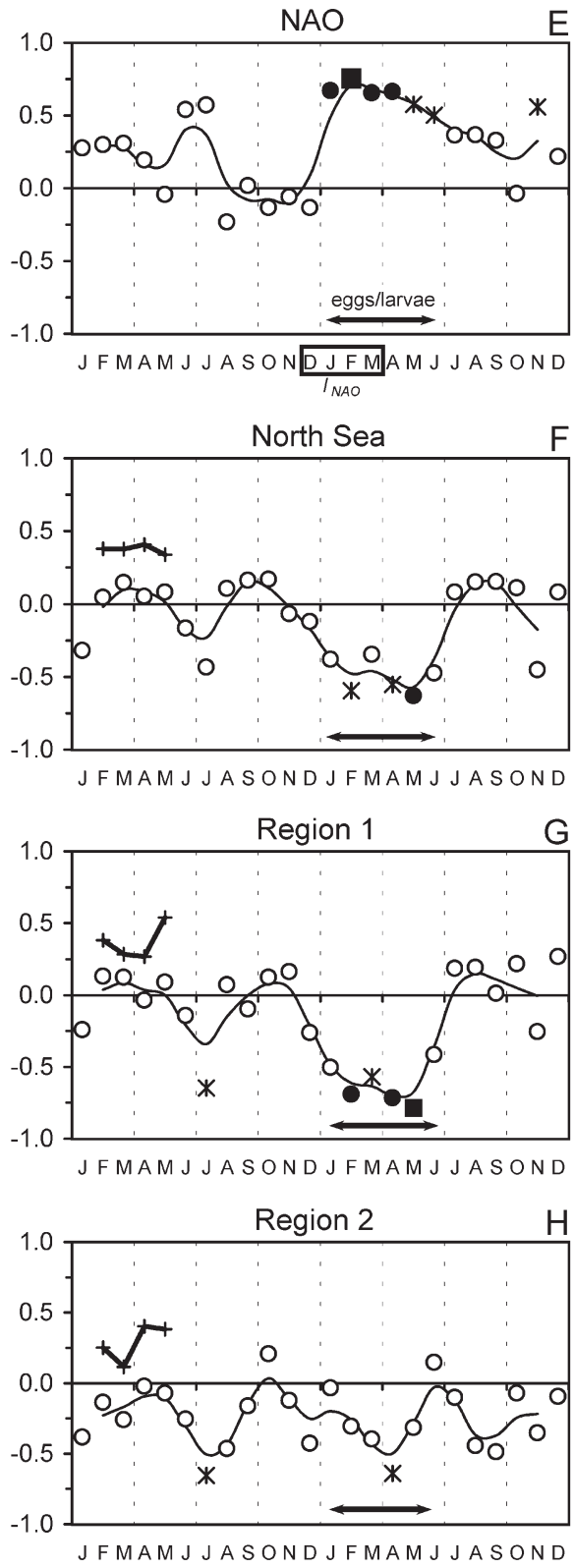

Fig. 2. Time series plots of Pearson product moment correlation coefficients ( $y$-axis of each graph) from monthly sea bottom temperature $(A-D)$ and sea surface temperature $(E-H)$ data. Monthly temperatures covering the year prior to recruitment and year of recruitment (arrows indicate egg/larval phase) were correlated with: (A,E) $I_{\mathrm{NAO}}$ (North Atlantic Oscillation [NAO] winter index during boxed months) for the year of recruitment; (B,F) recruitment residuals from the whole North Sea population; (C,G) recruitment residuals from the Region 1 population; $(\mathrm{D}, \mathrm{H})$ recruitment residuals from the Region 2 population. The recruitment residuals were derived from Eq. (2) (i.e. having accounted for the effects of spawning stock biomass and 1-group sandeels). The p-value of each correlation coefficient is represented by its symbol: $\mathrm{o}, \mathrm{p}>0.05 ; \boldsymbol{*}, \mathrm{p}<0.05 ; \bullet, \mathrm{p}<0.01 ; \mathbf{m}, \mathrm{p}<0.002$ (the Bonferroni corrected significance level is 0.002 in each instance). The fitted thin line is a centrally weighted 3-point moving average, inserted to show general month-to-month trends. (Four-point bold line plots in panels $\mathrm{F}$ to $\mathrm{H}$ show correlations between $T_{\mathrm{s}}$ and $\ln \left(N_{0}+1\right)$ data, rather than between $T_{\mathrm{s}}$ and Eq. (2) recruitment residuals; see 'Discussion' for more details)

same year $(\mathrm{r}=-0.763, \mathrm{p}=0.002)$. In general, across all 3 population data sets, correlations between $T_{\mathrm{b}}$ and $N_{0}$ and between $T_{\mathrm{s}}$ and $N_{0}$ produced coefficients that were negative in every instance across the months February to May in the year of recruitment (total of 24 correlations, range of $r$ values $=-0.15$ to -0.76 ). 
An even clearer picture emerged after accounting for the effects on recruitment of both $S$ and $N_{1}$ (residuals from Eq. 2; Fig. 2). These recruitment residuals produced stronger, more consistent correlations, coinciding with the egg and larval development period (predominantly January to May; Macer 1965, Langham 1971). Two significant relationships were detected with these residual data at the Bonferroni corrected $5 \%$ significance level $(p=0.002)$. North Sea recruitment was negatively correlated with $T_{\mathrm{b}}$ in April of the larval period $(r=-0.755, p<0.001)$, and Region 1 recruitment was negatively correlated with $T_{\mathrm{s}}$ during April $(\mathrm{r}=-0.786, \mathrm{p}<0.001)$. Overall, at both the North Sea and regional scales, the larval months coincided with periods of persistent negative correlations between recruitment and temperature. This effect was most pronounced in Region 1 and least pronounced in Region 2.

These results are summarised by the fact that, for the North Sea and Region 1, residuals from the $S+\ln \left(N_{1}+1\right)$ model (Eq. 2) correlated negatively with sea temperatures averaged across the egg/larval months of January to May (North Sea residuals, for $T_{\mathrm{b}}: \mathrm{r}=-0.561$, $\mathrm{p}=0.019$, for $T_{\mathrm{s}}: \mathrm{r}=-0.569, \mathrm{p}=0.017$; Region 1 residuals, for $T_{\mathrm{b}}: \mathrm{r}=-0.668, \mathrm{p}=$ 0.013 , for $T_{\mathrm{s}}: \mathrm{r}=-0.732, \mathrm{p}=0.004$; but in Region 2 residuals, for $T_{\mathrm{b}}: \mathrm{r}=-0.367, \mathrm{p}=$ 0.197 , for $T_{\mathrm{s}}: \mathrm{r}=-0.402, \mathrm{p}=0.154$; see Fig. 3).

Outside of the egg/larval period, a weak relationship between $S+\ln \left(N_{1}\right.$ +1 ) residuals (Eq. 2) and $T_{\mathrm{s}}$ in July of the year prior to recruitment was found (Fig. $2 \mathrm{~F}-\mathrm{H}$ ). This effect was strongest in Region $2(\mathrm{r}=-0.653, \mathrm{p}=0.011)$.

\section{Calanus zooplankton}

Both $N_{0}$ data and $S+\ln \left(N_{1}+1\right)$ residual data (Eq. 2) were compared against $C_{\mathrm{v}-v i}$ monthly counts covering the year before and the year of recruitment. The 2 sets of recruitment proxies produced similar results, with the main correlation trends being strengthened after accounting for $S$ and $N_{1}$. The correlations with $S+\ln \left(N_{1}+1\right)$ residuals (Fig. 4A-C) reveal a tendency towards positive relationships with $C_{\mathrm{v} \text {-vi }}$ during early stages of the egg/larval period. In Region 1, a strong positive relationship was found during February $(\mathrm{r}=$
$+0.861, \mathrm{p}<0.001$; cf. Bonferroni correction at $5 \%$ level: $\mathrm{p}=0.002)$. A slightly weaker correlation was found in the North Sea during February $(r=0.734, p=0.003)$, whereas no strong correlations were detected in Region 2.

Tests were performed to see whether $C_{\mathrm{v} \text {-vi }}$ over the egg/larval months of January to May was related to $I_{\mathrm{NAO}}$ or monthly $T_{\mathrm{s}}$. No significant correlations were detected with $I_{\text {NAO }}(0.08<\mathrm{p}<0.91)$. With $T_{\mathrm{s}}$ a negative relationship was found in February $(\mathrm{r}=-0.578, \mathrm{p}=$ $0.030, \mathrm{n}=14 \mathrm{yr}$ of data) and a positive relationship in April $(\mathrm{r}=0.660, \mathrm{p}=0.007)$.

Since $T_{\mathrm{s}}$ and $C_{\mathrm{v} \text {-vi }}$ may be related to one another as well as to sandeel recruitment, a series of month-bymonth regression analyses was performed in which both $T_{\mathrm{s}}$ and $C_{\mathrm{v} \text {-vi }}$ data from the month of interest were included as environmental parameters in Eq. (3). Either or both parameters were removed from the
Sea bottom temperature
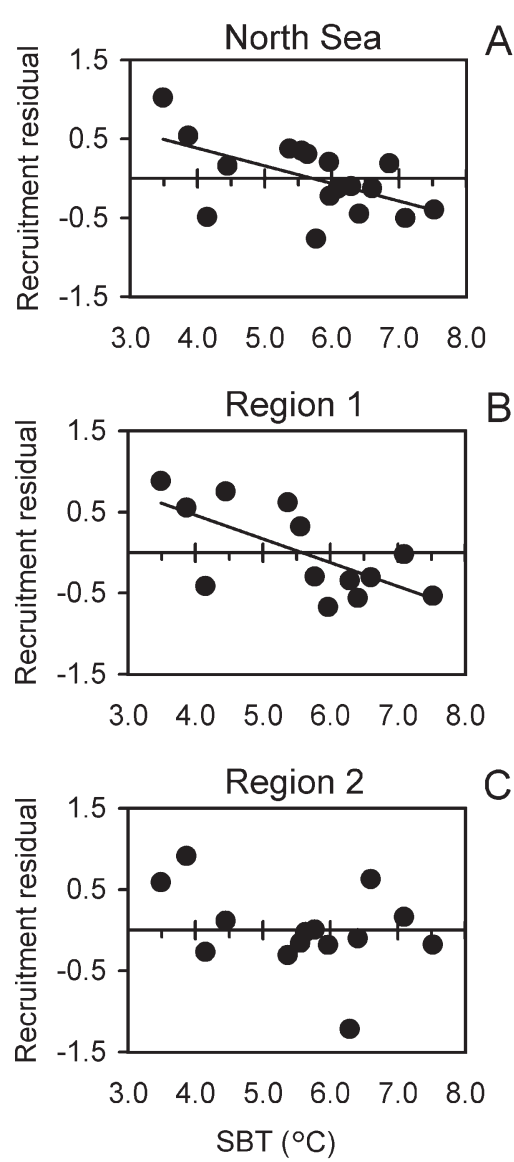

Sea surface temperature

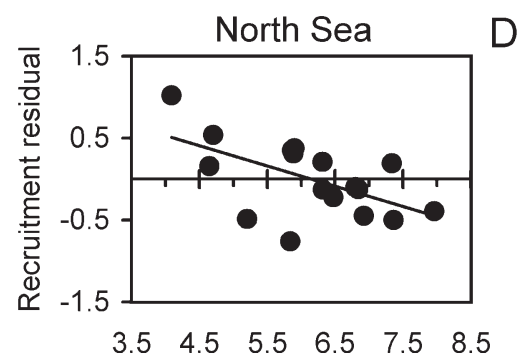

B
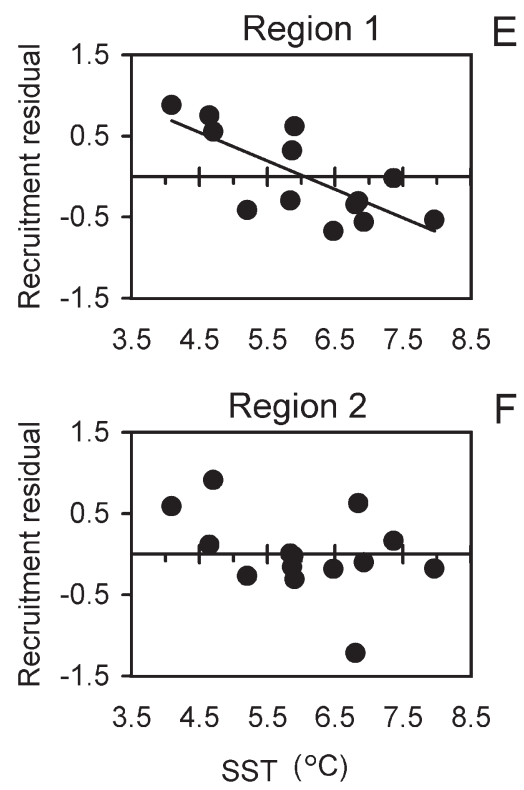

Fig. 3. Relationships of sandeel recruitment with sea bottom temperature (lefthand panels) and sea surface temperature (right-hand panels) data. Recruitment is expressed in terms of residuals from Eq. (2) (i.e. having accounted for the effects of spawning stock biomass and 1-group sandeels). (A,D) Whole North Sea recruitment; $(B, E)$ Region 1 recruitment; $(C, F)$ Region 2 recruitment. Fitted lines (linear regressions) are included in cases where the relationships were found to be significant 


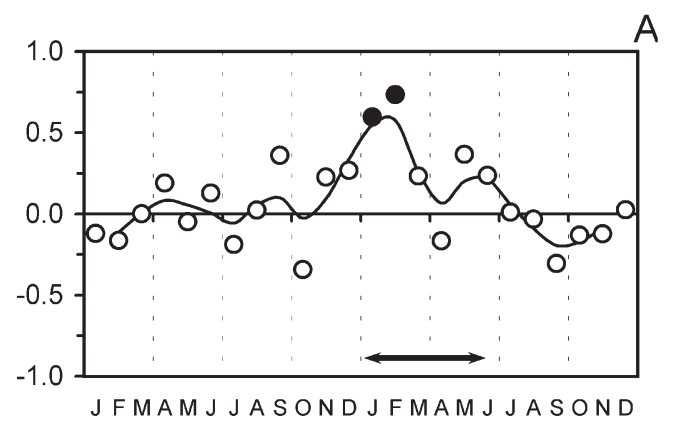

B
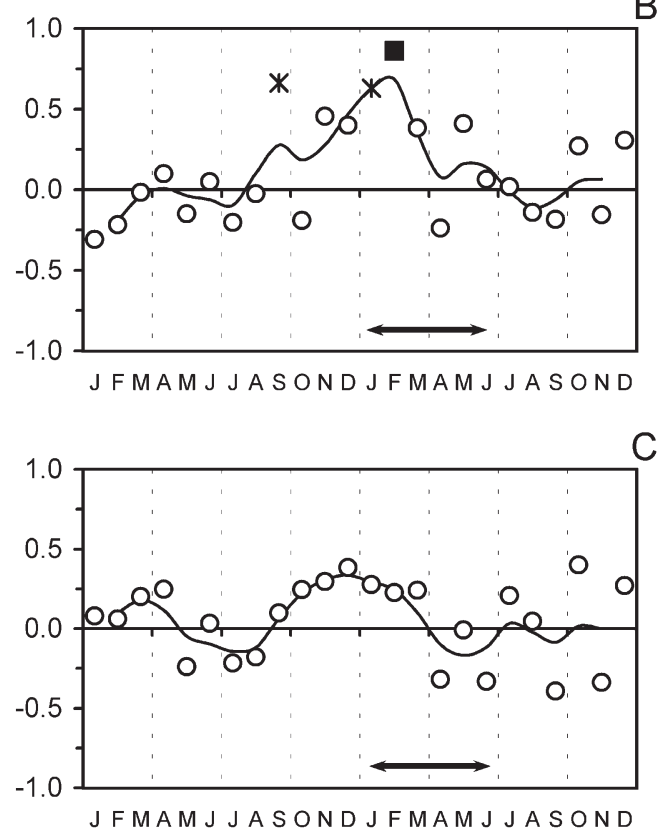

Fig. 4. Time series plots of Pearson product moment correlation coefficients ( $y$-axis of each graph) derived from monthly Calanus Stage V and VI counts. Monthly counts from the year prior to recruitment, and the year of recruitment (arrows along the $x$-axis show the egg and larval period), were correlated with recruitment residuals from Eq. (2) (accounting for the effects of spawning stock biomass and 1-group sandeels). (A) Recruitment to the whole North Sea. (B) Recruitment to Region 1. (C) Recruitment to Region 2. The p-value of each correlation coefficient is represented by its symbol: $0, p>$ $0.05 ; \boldsymbol{W}, \mathrm{p}<0.05 ; \bullet, \mathrm{p}<0.01 ; \mathbf{\mathbf { m }}, \mathrm{p}<0.002$ (the Bonferroni corrected significance level is 0.002 in each instance). The fitted line is a centrally weighted 3-point moving average, inserted to show general month-to-month trends

regression if their coefficients were found to be nonsignificant ( $t$-test). Interactive terms were also tested in the model, but were not found to be significant. The analyses (Table 3) indicate that, in the North Sea and Region $1, C_{\mathrm{v}-\mathrm{vi}}$ is a significant factor around the time of hatching (January to March), but that $T_{\mathrm{S}}$ is of more importance later on in development, between March and May. In Region 2, $C_{\mathrm{v} \text {-vi }}$ was never significant and $T_{\mathrm{S}}$ only had a comparatively weak effect during April.

\section{DISCUSSION}

Our analyses indicate that the spawning stock biomass, by itself, is a poor predictor of sandeel recruitment in the North Sea, and suggest that additional influences are exerted by environmental conditions and the demographic structure of the population. Recruitment was negatively related with sea temperature during the egg/larval stages, negatively related with the number of aged 1 sandeels (which comprise the majority of the population; Anonymous 1999) and positively related with feeding conditions during the egg/larval stages.

The sandeel population assessments performed by ICES calculate $S$ on the assumption that Age-2+ sandeels all spawn and that none of the $N_{1}$ sandeels spawn. However, it is known that a proportion of $N_{1}$ sandeels may in fact spawn, whereas not all of Age-2+ fish necessarily do so (Macer 1966, Gauld \& Hutcheon 1990). Since ca. 40 to $80 \%$ of the total stock biomass typically comprises $N_{1}$ in the first half of the year (Anonymous 1999), fairly large errors in estimating $S$ may arise. This may partly explain the lack of relationship between $S$ and recruitment, but the other effects that we have detected here are probably of greater importance in explaining the observed variability.

The negative relationship between $N_{1}$ and recruitment implies that density-dependent processes are taking place within the population, but the mechanism(s) by which these occur remain unclear. Since the demersal egg stages are laid within the sediment of the seabed, and sandeels apparently have no distinctly separated spawning grounds (Reay 1970), the eggs might be disrupted by the burying behaviour of established sandeels or cannibalised when they hatch. Alternatively, cannibalism and competition for seabed space and food could be important when the larvae settle from the plankton. Translocation of larvae from one area of seabed to another is thought to be the main means of inter-population mixing in sandeels because the adults are non-migratory (Procter et al. 1998). Therefore, understanding the meta-population dynamics of sandeels will require further studies into the proximate causes of density dependence at different stages of the sandeel lifecycle.

The autocorrelation coefficients produced from the recruitment analyses (Table 2) show interesting trends that shed light on sandeel recruitment processes. Both the actual recruitment data $\left(N_{0}\right)$ and residuals from the $S$ model (Eq. 1) produced significant negative autocorrelations at a lag of $1 \mathrm{yr}$. This was true in all cases, both at the whole North Sea and regional level. However, once the influence of $N_{1}$ had been taken into account (by examining residuals from the $S+\ln \left[N_{1}+1\right]$ model, as well as the $S+\ln \left[N_{1}+1\right]+I_{\mathrm{NAO}}$ model), the effect was no 
longer significant. This suggests that the density-dependent effects imposed by the $N_{1}$ sandeels are largely responsible for the alternating years of high and low recruitment. Intuitively, this makes sense, since a year of high recruitment results in high $N_{1}$ the following year, which will then compete with new arrivals. Modelling studies on rainbow smelt Osmerus mordax populations in Lakes Ontario and Erie support this notion (Lantry \& Stewart 2000). These authors found that fluctuating years of high and low recruitment could be explained by cannibalistic behaviour of Age-1+ fish, even when this mode of feeding behaviour operated at very low levels. Since adult sandeels are known to consume fish larvae (Reay 1970), cannibalism may explain the effects of 1-group sandeels that we detected.

The ecological effects of the NAO have been receiving increasing attention in recent years. There is strong evidence that during the winter and spring in northwest Europe, terrestrial, freshwater and oceanic conditions are closely associated with the atmospheric parameters incorporated within $I_{\text {NAO }}$ (Hurrell 1995) and that these influence ecological processes (e.g. Ottersen et al. 2001). In the North Sea, a positive link between sea temperature anomalies and $I_{\text {NAO }}$ were identified by Becker \& Pauly (1996), an effect also evident with our data (Fig. 2A,E). Moreover, we detected a negative relationship between $I_{\text {NAO }}$ and sandeel recruitment in the North Sea during the period from 1983 to 1999 . $I_{\mathrm{NAO}}$ may affect recruitment through a variety of mechanisms, but our results indicate that, whatever processes are responsible, they operate predominantly upon the egg and/or larval stages. Recruitment proxies were negatively related with both $T_{\mathrm{b}}$ and $T_{\mathrm{s}}$ during the egg/larval phases, with the general effect of $T_{\mathrm{s}}$ being stronger than $T_{\mathrm{b}}$ (Fig. 3). These relationships disappeared abruptly after larval settlement (Fig. 2B-D,F-H), which contrasts with the more gradual diminishment of relationships between $I_{\text {NAO }}$ and temperature during and beyond the egg/larval phase (Fig. 2A,E). Climatic factors during the early life stages of fishes have long been implicated as a cause of recruitment fluctuations. Around the UK, for example, plaice Pleuronectes platessa and dab Limanda limanda recruitment correlates negatively with sea temperature (Henderson 1998, Fox et al. 2000).

Myers (1998) noted that climatic correlations with recruitment often breakdown as subsequent years of data are accumulated, except in populations near the latitudinal limit of a species' range, where the relationships tend to remain robust with time. This suggests that the temperature effects we have detected here are of importance because the strongest influences were in the most southerly population (Region 1) and the effects were in the expected direction (i.e. poorer recruitment when conditions were warmer than usual). Region 1 ( 51 to $56^{\circ} \mathrm{N}$ ) lies close to the southern (equatorial) limit of Ammodytes marinus, which inhabits latitudes of between 49 and $73^{\circ} \mathrm{N}$ (Reay 1970). In Region 2 (55 to $59^{\circ} \mathrm{N}$ ), the climatic trends were weaker, but in the same direction as Region 1 (since the area still lies within the more equatorial half of the species' distribution). At the whole North Sea level, the strength of the climatic effects was intermediate, reflecting the fact that the data mainly integrate across both regions. The only exception to this was the weak negative link we detected between recruitment and $T_{\mathrm{s}}$ during July of the year preceding recruitment (Fig. 2F-H). This relationship was strongest in Region 2, thus reversing the trend that might otherwise be expected. However, sea surface temperature satellite images (http://www.bsh.de/ Oceanography/Climate/Actual.htm) reveal that, although Region 2 is generally cooler than Region 1 during the egg/larval period of the year, it is actually warmer during the summer months. This would explain the reversal, and perhaps indicates that the fitness of the parental fish is in some way compromised by excessive summer temperatures.

Temperature has the potential to influence the development of eggs and larvae directly by affecting their developmental patterns, growth rates and behavioural responses (e.g. Cushing 1995, Temple \& Johnston 1997, Johnston et al. 1998). Recruitment may also be affected by changes in the trophic structure of the 
ecosystem, either with respect to the feeding conditions experienced by the larvae (bottom-up responses) or predation threat (top-down responses); these processes are not mutually exclusive (Roff et al. 1988).

The occurrence of bottom-up effects was supported by the positive association we found between $C_{\mathrm{v}-\mathrm{vi}}$ and sandeel recruitment. Calanus is an important dietary item of sandeels (Reay 1970), and although Stage V and VI Calanus are probably too big to be eaten themselves by the smallest sandeel larval stages, their abundance provides a direct estimate of immediate Calanus nauplii production potential. We detected few strong associations between climatic factors and $C_{\mathrm{v} \text {-vi, }}$ but the data we analysed were averaged across all of North Sea Area IVb and did not distinguish between different species of Calanus, which respond differently to climatic signals. $I_{\text {NAO }}$ has been shown to influence oceanic inflow, primary production and zooplankton communities in the North Sea (Fromentin \& Planque 1996, Planque \& Fromentin 1996, Heyen et al. 1998), and therefore one would expect it also to affect the feeding conditions experienced by planktivores such as sandeels.

Sherman et al. (1981) attributed a rising abundance of sandeels on the opposite (northwest) side of the Atlantic to the over-exploitation of herring and mackerel (both sandeel predators), implying that top-down effects were dominant within the system. In the North Sea, herring are important predators of sandeel larvae (Hardy 1924), but tend to occupy more northerly areas during warm years (Corten 2001), which suggests that they were not responsible for the effects we detected, since the negative influence of warm conditions was most noticeable in the southern part of the North Sea (Region 1). Other means of top-down control may occur, however, and since this mechanism can have profound effects upon ecosystems (e.g. Verity \& Smetacek 1996, Post et al. 1999), it should not be discounted.

The response of pathogens to climatic regime may also be important, and although this mechanism may be of relevance to fish recruitment (Henderson 1998), standard fishery assessment methods do not investigate the year-to-year variation in fish health status, making it impossible to evaluate the role of pathogens.

It is also possible that the mechanism of climatic perturbation differs between regions, or from year-toyear. Hart (1974) proposed that temperature anomalies and the extent of Atlantic water penetration into the North Sea between 1948 and 1968 affected the sandeel larvae abundance measured in the concurrent continuous plankton recorder surveys. However, the implied relationships were not always in agreement with one another, indicating that responses may differ in time and space. With our data, residuals from the $S+\ln \left(N_{1}\right.$ +1 ) model (Eq. 2) in Region 1 correlated more strongly with mean $T_{\mathrm{s}}$ over the period from January to May than with $I_{\mathrm{NAO}}$, whereas in Region 2 the reverse situation was true. Thus, temperature may be a more important proximate cause in Region 1, whereas more indirect routes predominate in Region 2 .

Two of the main influences upon sandeel recruitment that we detected (the demographic structure of the population and climatic conditions) could have an interesting counter-active behaviour. If warm conditions lead to lower recruitment than might otherwise be expected, they will also lead to lower $N_{1}$ numbers the following year, thus reducing the density-dependent effects among subsequent recruits. In other words, if $y$ represents any given year, $T_{S_{1} y}$ (this year's egg/larval phase sea surface temperature) may indirectly affect $N_{0, y+1}$ (next year's recruitment) via its effects upon $N_{0, y}$ (this year's recruitment). If true, one would expect the following: (1) Positive correlations should exist between $T_{s, y}$ and $N_{0, y+1}$ and (2) This positive association should disappear after accounting for the effects of $N_{1, y+1}$ (i.e. by testing the residuals from Eq. 2). We tested whether $T_{S, Y}$ correlations during the months of February to May were significantly more positive with respect to $N_{0, y+1}$ than with respect to residuals from Eq. (2) (i.e. do the points along the bold lines in Fig. 2F to $\mathrm{H}$ lie significantly above the open circle points of the same month?). In each instance, we detected a significant difference, thus supporting the hypothesis that $T_{s, Y}$ positively influences recruitment in Year $y+1$ via its effects upon $N_{1, y+1}$ (paired $t$-test comparison between February and May monthly correlation coefficients, North Sea: $t_{3}=12.67, \mathrm{p}<0.0001$; Region 1: $t_{3}=6.19, \mathrm{p}=0.003$; Region $2: t_{3}=14.37, \mathrm{p}<$ $0.0001)$. Similar types of demographic/climatic interactions have been postulated in other species, such as the bass Dicentrarchus labrax (Henderson \& Corps 1997).

Current climate models predict that global conditions will become warmer over the next century (Crowley 2000, Stott \& Kettleborough 2002). Furthermore, it has been proposed that long-term warming of tropical waters, caused by human activity, has played an important role in driving the NAO towards an extreme positive phase during the last half century (Hoerling et al. 2001). Since climate forcing can have major effects upon fish populations (e.g. Finney et al. 2002), an obvious question leading on from our findings is: What effects will long-term changes in climate have upon sandeel populations in the North Sea, and the higher predators that feed on them? One expectation is that the southern limit of the species' distribution could shift northwards if conditions become warmer. With regard to sandeel fishing practices, sustainable harvest limits in the North Sea may decline with time if recruitment becomes compromised by rising temperatures, especially in more southerly areas (O'Brien et al. 2000). Identifying the proximate mecha- 
nisms by which temperature affects sandeel recruitment, particularly during the egg and larval stages, will assist in understanding such responses and making informed management decisions.

Acknowledgements. We would like to thank the International Council for the Exploration of the Sea for providing the temperature data and the Sir Alister Hardy Foundation for Ocean Science for providing the zooplankton data. We are very grateful to Drs. Peter Wright, Henrik Jensen, Andrea Belgrano and Chris Reid for their helpful assistance and comments on the work. Financial support for the project came from the European Commission.

\section{LITERATURE CITED}

Anonymous (1999) Report of the working group on the assessment of demersal stocks in the North Sea and Skagerrak. ICES CM 2000/ACFM:7. International Council for the Exploration of the Sea, Copenhagen

Anonymous (2001) Report of the working group on the assessment of demersal stocks in the North Sea and Skagerrak. ICES CM 2002/ACFM:01. International Council for the Exploration of the Sea, Copenhagen

Arnott SA, Ruxton GD, Poloczanska ES (2002) Stochastic dynamic population model of North Sea sandeels, and its application to precautionary management procedures. Mar Ecol Prog Ser 235:223-234

Bailey KM, Houde ED (1989) Predation on eggs and larvae of marine fishes and the recruitment problem. Adv Mar Biol 25:1-83

Becker GA, Pauly M (1996) Sea surface temperature changes in the North Sea and their causes. ICES J Mar Sci 53: $887-898$

Beverton RJH, Holt SJ (1957) On the dynamics of exploited fish populations. Ministry of Agriculture, Fisheries and Food, London (republished by Chapman and Hall, London, 1993)

Blaxter JHS, Batty RS (1985) The development of startle responses in herring larvae. J Mar Biol Assoc UK 65: $737-750$

Blaxter JHS, Fuiman LA (1990) The role of the sensory systems of herring larvae in evading predatory fishes. J Mar Biol Assoc UK 70:413-427

Chatfield C (1996) The analysis of time series: an introduction, 5th edn. Chapman and Hall/CRC, London

Corten A (2001) Northern distribution of North Sea herring as a response to high water temperatures and/or low food abundance. Fish Res 50:189-204

Crowley TJ (2000) Causes of climate change over the past 1000 years. Science 289:270-277

Cushing DH (1975) Marine ecology and fisheries. Cambridge University Press, Cambridge

Cushing DH (1995) Population production and regulation in the sea: a fisheries perspective. Cambridge University Press, Cambridge

Finney BP, Gregory-Eaves I, Douglas MSV, Smol JP (2002) Fisheries productivity in the northeastern Pacific Ocean over the past 2200 years. Nature 416:729-733

Fox CJ, Planque BP, Darby CD (2000) Synchrony in the recruitment time-series of plaice Pleuronectes platessa (L.) around the United Kingdom and the influence of sea temperature. J Sea Res 44:159-168

Fromentin JM, Planque B (1996) Calanus and environment in the eastern North Atlantic. 2: influences of the North Atlantic Oscillation in C. finmarchicus and C. helgolandicus. Mar Ecol Prog Ser 134:111-118

Furness RW (1999) Does harvesting a million metric tonnes of sand lance per year from the North Sea threaten seabird populations? Ecosystem approaches for fisheries management. University of Alaska Sea Grant College Program, AK-SG-99-01, Fairbanks, p 407-424

Gauld JA, Hutcheon JR (1990) Spawning and fecundity in the lesser sandeel, Ammodytes marinus Raitt, in the northwestern North Sea. J Fish Biol 36:611-613

Greenstreet SPR (1996) Estimation of the daily consumption of food by fish in the North Sea in each quarter of the year. Report No. 55. Scottish Fisheries Research, Aberdeen

Hardy AC (1924) The herring in relation to its animate environment. Part I. The food and feeding habits of the herring with special reference to the east coast of England. Fishery Investigations, Ministry of Agriculture and Fisheries, London, Series II, Vol. 7, No. 3, p 1-53

Hart PJB (1974) Distribution and long term changes in abundance of larval Ammodytes marinus (Raitt) in the North Sea. In: Blaxter JHS (ed) Early life history of fish. SpringerVerlag, Berlin, p 171-182

Hayward TL (1997) Pacific Ocean climate change: atmospheric forcing, ocean circulation and ecosystem response. Trends Ecol Evol 12:150-154

Henderson GTD (1953) Continuous plankton records: the ground fish and fish eggs, 1932-39 and 1946-49. Hull Bull Mar Ecol 3:215-252

Henderson PA (1998) On the variability in dab Limanda limanda recruitment: a zoogeographic study. J Sea Res 40: 131-142

Henderson PA, Corps M (1997) The role of temperature and cannibalism in interannual recruitment variation of bass in British waters. J Fish Biol 50:280-295

Heyen H, Fock H, Greve W (1998) Detecting relationships between the interannual variability in ecological time series and climate using a multivariate statistical approach - a case study on Helgoland Roads zooplankton. Clim Res 10: 179-191

Hilborn R, Walters CJ (1992) Quantitative fisheries stock assessment: choice, dynamics and uncertainty. Chapman and Hall, London

Hjort J (1914) Fluctuations in the great fisheries of northern Europe. Rapp P-V Reun Cons Int Explor Mer 20:1-228

Hoerling MP, Hurrell JW, Xu T (2001) Tropical origins for recent North Atlantic climate change. Science 292:90-92

Hofmann EE, Powell TM (1998) Environmental variability effects on marine fisheries: four case histories. Ecol Appl (1)8:S23-S32 Suppl S

Hollowed AB, Hare SR, Wooster WS (2001) Pacific Basin climate variability and patterns of Northeast Pacific marine fish production. Prog Oceanogr 49:257-282

Hurrell JW (1995) Decadal trends in the North Atlantic Oscillation: regional temperatures and precipitation. Science 269:676-679

Jennings S, Kaiser MJ, Reynolds JD (2001) Marine fisheries ecology. Blackwell Scientific Publishers, Oxford

Johnston IA, Cole NJ, Abercromby M, Vieira VLA (1998) Embryonic temperature modulates muscle growth characteristics in larval and juvenile herring. J Exp Biol 201: 623-646

Langham NPE (1971) The distribution of and abundance of larval sand-eels (Ammodytidae) in Scottish waters. J Mar Biol Assoc UK 51:697-707

Lantry BF, Stewart DJ (2000) Population dynamics of rainbow smelt (Osmerus mordax) in Lakes Ontario and Erie: a 
modeling analysis of cannibalism effects. Can J Fish Aquat Sci 57:1594-1606

Macer CT (1965) The distribution of larval sandeels (Ammodytidae) in the southern North Sea. J Mar Biol Assoc UK 45:187-207

Macer CT (1966) Sand eels (Ammodytidae) in the southwestern North Sea: their biology and fishery. Ministry of Agriculture, Fisheries and Food: Fishery Investigations Series II, Vol XXIV, No. 6, Her Majesty's Stationery Office, London, p 1-55

Myers RA (1998) When do environmental-recruitment correlations work? Rev Fish Biol Fish 8:285-305

O'Brien CM, Fox CJ, Planque B, Casey J (2000) Fisheriesclimate variability and North Sea cod. Nature 404:142

Ottersen G, Planque B, Belgrano A, Post E, Reid PC, Stenseth NC (2001) Ecological effects of the North Atlantic Oscillation. Oecologia 128:1-14

Pedersen SA, Lewy P, Wright P (1999) Assessments of the lesser sandeel (Ammodytes marinus) in the North Sea based on revised stock divisions. Fish Res 41:221-241

Planque B, Fromentin JM (1996) Calanus and environment in the eastern North Atlantic. 1: spatial and temporal patterns of C. finmarchicus and C. helgolandicus. Mar Ecol Prog Ser 134:101-109

Pope JG, Shepherd JG, Webb J (1994) Successful surf-riding on size spectra: the secret of survival in the sea. Phil Trans R Soc Lond B Biol Sci 343:41-49

Post E, Peterson RO, Stenseth NC, McLaren BE (1999) Ecosystem consequences of wolf behavioural response to climate. Nature 401:905-907

Procter R, Wright PJ, Everitt A (1998) Modelling the transport of larval sandeels on the north-west European shelf. Fish Oceanogr 7:347-354

Reay PJ (1970) Synopsis of the biological data on North Atlantic sand eels of the genus Ammodytes. Fisheries Synopsis No. 82. Food and Agriculture Organization of the United Nations, Rome

Reid PC, Edwards M, Hunt HG, Warner AJ (1998) Phyto-

Editorial responsibility: Otto Kinne (Editor),

Oldendorf/Luhe, Germany plankton change in the North Atlantic. Nature 391:546

Ricker WE (1954) Stock and recruitment. J Fish Res Board Can 11:559-623

Roff JC, Middlebrook K, Evans F (1988) Long term variation in North Sea zooplankton. J Mar Biol Assoc UK 68: 143-164

Shepherd JG (1982) A versatile new stock-recruitment relationship for fisheries and the construction of sustainable yield curves. J Cons 40:67-75

Sherman K, Jones C, Sullivan L, Smith W, Berrin P, Ejsymont L (1981) Congruent shifts in sand eel abundance in western and eastern north-Atlantic ecosystems. Nature 291: 486-487

Stott PA, Kettleborough JA (2002) Origins and estimates of uncertainty in predictions of twenty-first century temperature rise. Nature 416:723-726

Temple GK, Johnston IA (1997) The thermal dependence of fast-start performance in fish. J Therm Biol 22:391-401

Thompson PM, Ollason JC (2001) Lagged effects of ocean climate change on fulmar population dynamics. Nature 413:417-420

Verity PG, Smetacek V (1996) Organism life cycles, predation, and the structure of marine pelagic ecosystem. Mar Ecol Prog Ser 130:277-293

Winslade P (1974a) Behavioural studies on the lesser sandeel Ammodytes marinus (Raitt). I. The effect of food availability on activity and the role of olfaction in food detection. J Fish Biol 6:565-576

Winslade P (1974b) Behavioural studies on the lesser sandeel Ammodytes marinus (Raitt). II. The effect of light intensity on activity. J Fish Biol 6:577-586

Winslade P (1974c) Behavioural studies on the lesser sandeel Ammodytes marinus (Raitt). III. The effect of temperature on activity and the environmental control of the annual cycle of activity. J Fish Biol 6:587-599

Wright PJ, Jensen H, Tuck I (2000) The influence of sediment types on the distribution of the lesser sandeel, Ammodytes marinus. J Sea Res 44:243-256

Submitted: December 11, 2001; Accepted: April 30, 2002 Proofs received from author(s): July 23, 2002 